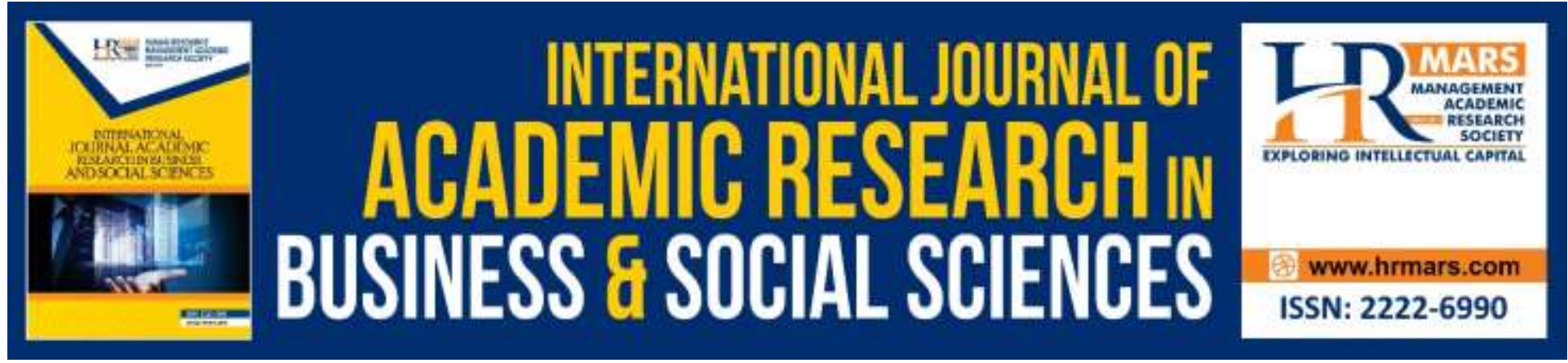

\title{
Issues and Challenges in Modeling Relationships between College Choice Factors and Student Retention on Academic Achievement in Pre-University Students
}

Vikneshwary Muniyandi, Ramlee bin Ismail

To Link this Article: http://dx.doi.org/10.6007/IJARBSS/v9-i7/6185

DOI: $10.6007 /$ IJARBSS/v9-i7/6185

Received: 07 May 2019, Revised: 14 June 2019, Accepted: 30 June 2019

Published Online: 08 July 2019

In-Text Citation: (Muniyandi \& Ismail, 2019)

To Cite this Article: Muniyandi, V., \& Ismail, R. bin. (2019). Issues and Challenges in Modeling Relationships between College Choice Factors and Student Retention on Academic Achievement in Pre-University Students. International Journal of Academic Research in Business and Social Sciences, 9(7), 862-868.

Copyright: (C) 2019 The Author(s)

Published by Human Resource Management Academic Research Society (www.hrmars.com)

This article is published under the Creative Commons Attribution (CC BY 4.0) license. Anyone may reproduce, distribute, translate and create derivative works of this article (for both commercial and non-commercial purposes), subject to full attribution to the original publication and authors. The full terms of this license may be seen

at: http://creativecommons.org/licences/by/4.0/legalcode

Vol. 9, No. 7, 2019, Pg. 862 - 868

http://hrmars.com/index.php/pages/detail/IJARBSS

JOURNAL HOMEPAGE

Full Terms \& Conditions of access and use can be found at http://hrmars.com/index.php/pages/detail/publication-ethics 


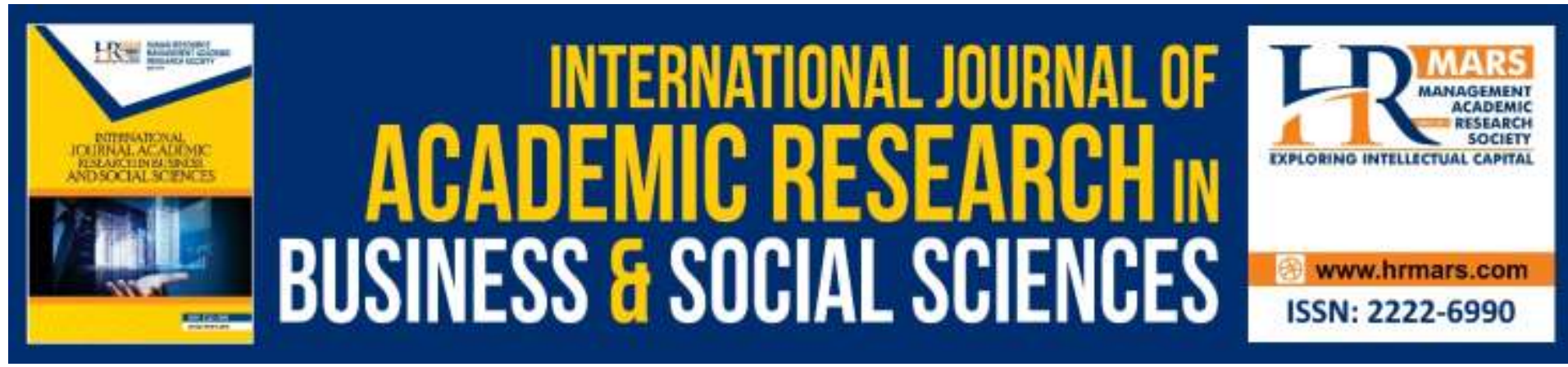

\title{
Issues and Challenges in Modeling Relationships between College Choice Factors and Student Retention on Academic Achievement in Pre- University Students
}

\author{
Vikneshwary Muniyandi, Ramlee bin Ismail \\ Faculty of Management and Economics, Universiti Pendidikan Sultan Idris, 35900 Tanjong \\ Malim, Perak, Malaysia
}

\begin{abstract}
The purpose of this study is to build a Relationship Model between College Choice Factor and Student Retention on Achievement among Pre-university Students in the State of Selangor, Malaysia. This study examines issues related to choice factors and retention of students. This research can be a source of references at the planning stage of national education policy. Challenges in choice factors and retention of students comprise international education. The implication of this study is expected to provide additional information on student selection and retention factors as well as providing guidance to the Ministry of Education (MOE) to improve the structure of pre-university education.
\end{abstract}

Keywords: Issues, Challenges, Selection Factors, Retention Factors, Academic Achievements

\section{Introduction}

Recognizing the fact that the country is facing the globalization era, the Ministry of Education (MOE) has to take a change in educational policy so that the country can compete in line with the quality of international education. The Ministry of Education Malaysia (MOE) strives to provide the best educational opportunities, appropriate and accurate with the needs of preschool, primary, secondary and secondary education to continue learning before going to institutions of higher learning. Therefore, the government has taken a drastic step in transforming education through the initiative of the Ministry of Education Malaysia (MOE) to develop the Education Development Plan 2013-2025.

The structure of pre-university education is also changing as the state education system aspires. The Malaysian Education Development Plan (PPPM) 2013-2025 has been developed to ensure that the quality of the curriculum is in line with international standards. The Ministry also sees the country's need to produce high quality human capital that is capable of competing internationally. In this regard, it is the responsibility of the ministry to build an education policy that can produce a balanced and resilient student.

Similarly with the introduction of the new curriculum system of the Secondary Standard School Curriculum (KSSM) in 2017. In line with the changes in the Secondary School 
Standard Curriculum (KSSM), Pre-university Assessment has also undergone a change in accordance with the current demands of the change in the terminal system to the modular system. In the modular assessment system, cognitive skills, manipulative skills, and soft skills are applied. Students should be provided with soft skills that include communication skills, teamwork, leadership, critical thinking, information management and ethics and morals (Ministry of Education, 2012). Hence, the transformation of pre-university education is an important agenda of the ministry in PPPM 2013-2025 by formulating curriculum changes from the usual school system to pre-university education system. Aspects of management as well as teaching and learning are changing to attract more students to pre-university education. This shows the ministry's desire to create excellence in the Malaysian Higher School Certificate (STPM) examinations to further their studies in institutions of higher learning (IPT) in and outside the country (Ministry of Education, 2012).

\section{Issues in Pre-University Student Selection and Retention}

The National Philosophy of Education aims to create a balanced and harmonious human, physical, emotional, spiritual and intellectual human capital to meet the challenges of the 21st century. Hence, the transformation of the pre-university structure of study which undergoes a process of change in line with the aspiration of national education is essential to equip students who will claim knowledge in the environment of higher learning institutions. Therefore, teachers must be high quality in order to produce critical thinking that can be competitive internationally.

The development of the relationship model between the selection and retention factor of this student can be the basis of realization of the national education transformation program. The model of the relationship between the selection and retention factor of the students can be a reference to the more structured study structure planning to meet the aspirations of students as contained in the National Education Blueprint 2013-2025. In order to produce quality and competitive human capital, the Ministry of Education Malaysia (MOE) provides a wide range of options for secondary education to have a solid foundation for preparations at the tertiary level (Annual Report of the Malaysian Education Development Plan, 2017). Changes in the pre-university education structure give an impression on the selection. Therefore, the choice to the institution of study among students is influenced by various factors and should be investigated as the selection will affect the retention of preuniversity students. Selection and retention factors will influence the academic achievement of students to be globally competitive.

\section{Challenges in Pre-University Student Selection and Retention}

The strategy to upgrade pre-university education in line with its status in improving the quality of education is implemented by introducing pre-university concepts based on the mode of study, a new curriculum assessment system for soft skills development and leadership talent (National Education Policy, 2017). The transformation of pre-university studies aimed at attracting more students in enhancing enrollment is implemented in 2013 (Annual Report of Malaysia's Education Development Plan, 2013). However, the initial enrollment of Form Six students from 2013 to 2017 still shows an inconsistent pattern of fluctuating patterns as detailed in the table. 
Table 1.1

Six-Form Student Enrollment (2013-2017)

\begin{tabular}{ll}
\hline Year & Student Enrollment \\
\hline 2013 & 110,952 \\
2014 & 94,784 \\
2015 & 92,572 \\
2016 & 97,482 \\
2017 & 98,073 \\
Total & 493,863 \\
\hline
\end{tabular}

Source: (Education Policy Planning and Research Division (MOE, 2017)

This situation proves that many students have yet to receive pre-university education as a preference for secondary education as the preferred institution for further education. Likewise, the retention of students in pre-university institutions after registering but quit immediately after registration due to various offers from Private Institutions of Higher Learning (IPTS).

The concept of centralization of pre-university based on the mode of study is carried out where schools have been grouped into three modes namely the Form Six Form 1 College known as Form Six College (Mode 1), Form Six Center (Mode 2) (school name) and Form Six (Mode 3) (school name) (Form Six Management Guidelines, 2016). The restructuring of schools by mode of study into Form Six College and Form Six Center has undergone a change since 2014. In 2014, a total of 5 schools across Malaysia were implemented Mod 1 school known as Form Six College Mod 1 and one additional school in 2015. A total of 47 schools have the Sixth Mode 2 Form Center in 2015 and the remainder are still known as Form Six Form 6. Up to 2017, a total of 15 new Form Six Mode 2 centers have been operating and the number of Form Six in Malaysia overall is 630 (14 College Form Six Mode 1, 78 Form Six Mode 2 and 538 Form Six Mode 3 Modules as in Table 1.2 (Annual Report of Malaysian Education Development Plan, 2017).

The data shows the number of Form Six Form 2 and Form Six Form 3 still operating until the end of the Second Wave, Malaysia's Education Development Plan (2016-2020). This situation is very different from the number of other Tertiary Education Programs such as Matriculation Program, Foundation Program, Community College, Polytechnic, IPTA Diploma, Private College, Private Universities, Mara College, School of Foreign Studies and Preparatory Centers (Hasan, Hamidah \& Talib, 2013).

At the end of the semester, the students will sit for the Malaysian High School Certificate (STPM) assessment according to the provisions of the Malaysian Examinations Council Act 1980 [National Education Policy, 2017]. The Malaysian High School Assessment System (STPM) assessment system in the terminal system in Form Six studies before 2013 poses the difficulties that cause transformation to the benefit of the students. Changes in preuniversity education systems from terminal systems to modular systems result in syllabus and examination systems changing. Changes in syllabus and exams affect student achievement. Based on the STPM Assessment System according to the terminal system, student assessment is only focused on examination based on the examination that the student will sit for the 
examination after one and a half years of study (Shaari 2013). This method imposes on students as assessed starting from the first year of the school session and is only an examination-oriented whose overall student achievement is based on a centralized examination (Malaysian Examination Council (MPM), 2012).

Meanwhile, in the new assessment system, the modular system of the overall results of the STPM examination is determined based on the best combination of results for all three semester exams. According to the Malaysian Examination Council, MPM (2012), the STPM New Assessment System is divided into two forms, based on final examination and School Based Assessment (PBS). Final examination conducted by three semesters fully conducted by the Malaysian Examination Council (MPM) and PBS included weighted values in the determination of students' performance in the examination. Students can see and improve the results in the final semester of the exam (Malaysian Examination Council (MPM), 2012). Academic achievement is seen with the Overall Grade Value (CGPA) of the Malaysian Examinations Certificate of Higher Education (STPM) since the implementation of the modular exam approach compared to the terminal (Annual Report of the Malaysian Education Development Plan, 2017).

The selection and retention of students to institutions of study among these preuniversity students are influenced by various factors and need to be investigated as it has long-term effects, especially in terms of student academic achievement. Studies show that there are several models in the process of selecting students to college by developing select models in the decision-making process (Lansing, 2017). Selected models were also presented by scholars in their studies regarding the choice of students to college (Mosely 2016; Tamtekin Aydın 2016; Migin, 2015; Lee 2015; Hossler and Gallagher 2014; Bergerson, Heiselt \& Aiken, 2013; Songan et al 2010; Duit, 2007). Most studies also explain the models of this collegebuilt option that enable an individual to understand the factors that influence the selection process (Wilson and Adelson, 2015). An individual needs to go through a rational decisionmaking process of choice to college carefully (Migin, 2015). Retention in college is based on the experience of college students who will make it either permanent or otherwise. According to Astin (1985), the background of students and the environment of the institution of learning affects the retention of the students to continue their learning to improve their academic achievement. Retention models were also presented by scholars in their studies regarding the factors of retention of students to college (Pellew, 2016; Hutto 2015; Valentine, Hirschy \& Bremer 2015; Packham et al., 2004). Therefore, an individual's choice process is influenced by various factors and rational choices will influence its retention in the institution and will then determine academic achievement in line with the goal of the Malaysia Education Blueprint 2013-2025 to produce a balanced and highly skilled student and can compete in this era of globalization.

In this regard, a study of student selection and retention model that has an impact on academic achievement and can provide a deeper understanding of the selection and retention model that needs to be carried out in the context of education in the eastern country, especially in Malaysia.

\section{Conclusion and Future Agenda}

Changes need to be made in line with the needs of the education ministry to provide a young generation with skills in line with current technological developments. This study is 
expected to provide additional information in the theory of selection and retention and provide guidelines on intervention measures to enhance pre-university student preferences and supplementary information to the Malaysian Examinations Council (MPM) to further increase the demand and supply of the Malaysian High School Certificate (STPM) program from terms of field diversity to be the choice of students after Sijil Pelajaran Malaysia (SPM).

\section{References}

Hasan, A. D., Hamidah, Y., \& Talib. A. M. H. (2013). Pola Pemilihan Program Pengajian Tertier Selepas Sijil Pelajaran Malaysia. Majlis Peperiksaan Malaysia (MPM). Percetakan Salam. Astin, A. (1985). Who Goes Where to College? Chicago: Science Research Associates.

Muniyandi, V., \& Ismail, R. bin. (2019). Issues and Challenges in Modeling Relationships between College Choice Factors and Student Retention on Academic Achievement in Pre-University Students. International Journal of Academic Research in Business and Social Sciences, 9(7), 726-735.

Kebangsaan, D. P. (2017). Bahagian Perancangan dan Penyelidikan Dasar Pendidikan, Kementerian Pelajaran Malaysia. Obtained from https://www.moe.gov.my/images/KPM/UKK/2019/03_Mac/BUKU_DPK_JILID_KEEMPA T.pdf

Duit, R. (2007). Eurasia Journal of Mathematics, Science and technology Education. Science Education Research Internationally: Conceptions, Research Methods, Domains of Research, 3(1), 3-15.

Garis Panduan Pengurusan Tingkatan Enam. (2016). Obtained from https://ppusmkst.files.wordpress.com/2011/03/3-garis-panduan-pengurusan-ting6.pdf

Hossler, D., \& Gallagher, K. S. (2014). Studying college choice: A three-phase model and the implications for policy-makers. College and University, 62(3), 207-221.

Hutto, P. N. (2016). The relationship between student retention in community college courses and faculty employment status courses and faculty employment status, 8926(April). https://doi.org/10.1080/10668926.2015.1069227

Kementerian Pendidikan Malaysia (2013). Pelan Pembangunan Pendidikan Malaysia 2013- 2025. Putrajaya: Kementerian Pendidikan Malaysia.

Kementerian Pendidikan Malaysia. (2012). Obtained from https://moe.gov.my/index.php/my/

Muniyandi, V., \& Ismail, R. bin. (2019). Issues and Challenges in Modeling Relationships between College Choice Factors and Student Retention on Academic Achievement in Pre-University Students. International Journal of Academic Research in Business and Social Sciences, 9(7), 726-735.

Muniyandi, V., \& Ismail, R. B. (2019). Issues and Challenges in Modeling Relationships between College Choice Factors and Student Retention on Academic Achievement in Pre-University Students. International Journal of Academic Research in Business and Social Sciences, 9(7), 726-735.

Malaysia, L. T. P. P. P. (2017). Unit Pelaksanaan dan Prestasi Pendidikan (PADU). Obtained from https://www.moe.gov.my/images/KPM/PADU/PADU-LAPORAN-TAHUNAN-BM2017.pdf

Majlis Peperiksaan Malaysia. (2012). Obtained from ttp://portal.mpm.edu.my/stpm1 
Muniyandi, V., \& Ismail, R. bin. (2019). Issues and Challenges in Modeling Relationships between College Choice Factors and Student Retention on Academic Achievement in Pre-University Students. International Journal of Academic Research in Business and Social Sciences, 9(7), 726-735.

Muniyandi, V., \& Ismail, R. B. (2019). Issues and Challenges in Modeling Relationships between College Choice Factors and Student Retention on Academic Achievement in Pre-University Students. International Journal of Academic Research in Business and Social Sciences, 9(7), 726-735.

Muniyandi, V., \& Ismail, R. B. (2019). Issues and Challenges in Modeling Relationships between College Choice Factors and Student Retention on Academic Achievement in Pre-University Students. International Journal of Academic Research in Business and Social Sciences, 9(7), 726-735.

Pelan Pembangunan Pendidikan Malaysia, PPPM 2013-2025. (2013). Obtained from https://www.moe.gov.my/index.php/dasarmenu/pelan-pembangunan-pendidikan2013-2025

Muniyandi, V., \& Ismail, R. B. (2019). Issues and Challenges in Modeling Relationships between College Choice Factors and Student Retention on Academic Achievement in Pre-University Students. International Journal of Academic Research in Business and Social Sciences, 9(7), 726-735.

Shaari, A. S. (2011). Pedagogi dari Sekolah ke Institusi Pendidikan Tinggi. Universiti Utara Malaysia. Sintok.

Muniyandi, V., \& Ismail, R. B. (2019). Issues and Challenges in Modeling Relationships between College Choice Factors and Student Retention on Academic Achievement in Pre-University Students. International Journal of Academic Research in Business and Social Sciences, 9(7), 726-735.

Muniyandi, V., \& Ismail, R. B. (2019). Issues and Challenges in Modeling Relationships between College Choice Factors and Student Retention on Academic Achievement in Pre-University Students. International Journal of Academic Research in Business and Social Sciences, 9(7), 726-735.

Muniyandi, V., \& Ismail, R.B. (2019). Issues and Challenges in Modeling Relationships between College Choice Factors and Student Retention on Academic Achievement in PreUniversity Students. International Journal of Academic Research in Business and Social Sciences, 9(7), 726-735.

Muniyandi, V., \& Ismail, R. B. (2019). Issues and Challenges in Modeling Relationships between College Choice Factors and Student Retention on Academic Achievement in Pre-University Students. International Journal of Academic Research in Business and Social Sciences, 9(7), 726-735. 